\title{
Intensitas Penggunaan Gawai Terhadap Kecerdasaan Emosional Mahasiswa
}

\section{Supriyadi}

\author{
Program Studi Pendidikan Ekonomi, Universitas Panca Sakti Bekasi \\ Correspondence author: supriyadi@panca-sakti.ac.id
}

DOI : https://doi.org/10.37012/jipmht.v4i1.457

\begin{abstract}
Abstrak
Penelitian ini bertujuan untuk mengungkap intensitas penggunaan gawai $(\mathrm{X})$ terhadap kecerdasan emosional mahasiswa Program Studi Pendidikan Ekonomi Universitas Panca Sakti Bekasi (Y). Penelitian ini menggunakan jenis penelitian kuantitatif dengan pendekatan survei. Sampel penelitian ini menggunakan teknik random sampling. Jumlah sampel penelitian sebanyak 43 mahasiswa. Pengambilan data menggunakan instrumen yang valid dan reliabel. Analisis data menggunakan regresi sederhana. hasil penelitian mengungkapkan: (1) Persamaan Linear Regresi $\mathrm{Y}=32,341+0,652 \mathrm{X}$ (2) Intensitas penggunaan gawai mahasiswa berpengaruh positif terhadap kecerdasan emosional mahasiswa. (3) Uji signifikansi didapat persamaan garis regresi $\mathrm{F}$ hit lebih kecil dari 0,05 dengan demikian, regresi $\mathrm{Y}$ atau $\mathrm{X}$ adalah signifikan atau intensitas penggunaan gawai berpengaruh terhadap kecerdasan emosional mahasiswa. (4) Koefisien korelasi (rxy) = 0,652 dan Fhit (Fchange) $=32,341$, dengan pvalue lebih kecil dari 0,05. Dengan demikian, koefisien korelasi $\mathrm{X}$ dan $\mathrm{Y}$ adalah berarti atau signifikan. Koefisien determinasi 0,652 , yang mengandung makna bahwa $65,2 \%$ variasi variabel kecerdasan emosional mahasiswa.
\end{abstract}

Kata kunci: Intensitas Penggunaan Gawai, Kecerdasan Emosional

\begin{abstract}
This study aims to reveal the intensity of the use of the device $(X)$ on the emotional intelligence of students in the Economic Education Study Program of Panca Sakti University, Bekasi (Y). This research uses quantitative research with a survey approach. The sample technique uses stage random sampling. The research sample consisted of 43 students. Retrieval of data using valid and reliable instruments. Data analysis using simple regression. The conclusions of the research results reveal: (1) Linear Regression Equation $Y=32.341+0.652 X$ (2) The intensity of the use of student devices has a positive effect on students' emotional intelligence. (3) The significance test shows that the $F$ hit regression line equation is smaller than 0.05 , thus, the $Y$ or $X$ regression is significant or the intensity of the use of the device has an effect on the emotional intelligence of students. (4) The correlation coefficient $($ rxy $)=0.652$ and Fhit $($ Fchange $)=32.341$, with a p-value less than 0.05. Thus, the correlation coefficients $X$ and $Y$ are meaningful or significant. The coefficient of determination is 0.652 , which means that $65.2 \%$ of the variation in the student's emotional intelligence variable.
\end{abstract}

Keywords: Intensity of Using Devices, Emotional Intelligence 


\section{PENDAHULUAN}

Pesatnya perkembangan ilmu teknologi diabad 21 dengan tujuan mempermudah ruang gerak dan ruang lingkup manusia diciptakan satu persatu setiap tahunnya. Ini membuktikan bahwa daya pikir masyarakat dan juga pola perilaku manusia semakin maju dan berkembang. Peran penemu-penemu sebelumnya dalam peningkatan hasil temuan yang lebih canggih sangat dominan. Perkembangan gadget dari masa ke masa dimulai dari perangkat yang bernama Handphone (HP). Handphone perkembangan dari pesawat elektronik telephone.

Hampir setiap individu mulai dari anak-anak hingga orang tua kini memiliki handphone atau smartphone. Tentu saja hal ini bukan hanya terjadi tanpa alasan karena daya konsumsi dan kebutuhan masyarakat saat ini sudah sangat jauh berbeda dibandingkan beberapa dekade ke belakang. Kebutuhan akan komunikasi dan informasi menjadi hal yang paling penting bagi semua kalangan masyarakat, di tambah dengan mudahnya mengakses berbagai macam fitur yang ditawarkan dari penyedia jasa layanan dari produsen smartphone itu sendiri dan berbagai provider pendukung.

Gawai memiliki fitur menarik yang ditawarkan dan seringkali membuat anak-anak cepat akrab. Banyak manfaat positif yang diperoleh dari penggunaan gawai yang dikemukakan oleh psikolog Hadiwidjodjo, Psi (2014) yaitu: Mempermudah Komunikasi. Gawai merupakan salah satu alat yang memiliki teknologi yang canggih. Jadi semua orang dapat dengan mudah berkomunikasi. Membangun kreatifitas (Gawai memberikan beragam informasi yang juga bisa mendorong menjadi lebih kreatif). Informasi diperoleh dengan mudah oleh seorang melalui gawainya dari mulai informasi berita, hobby dan permainan dengan istilah belajar sambil bermain dan bermain sambil belajar.

Ma'ruf (2015) Gawai adalah sebuah benda (alat atau barang eletronik) teknologi kecil yang memiliki fungsi khusus, tetapi sering diasosiasikan sebagai sebuah inovasi atau barang baru. Gawai selalu diartikan lebih tidak biasa atau didisain secara lebih pintar dibandingkan dengan teknologi normal pada masa penemuannya. Gawai merupakan salah satu teknologi yang sangat berperan pada era globalisasi ini. Sekarang gawai bukanlah benda yang asing lagi, 
hampir semua orang memilikinya. Tidak hanya masyarakat perkotaan, gawai juga dimiliki oleh masyarakat pedesaan.

Gawai merubah pola hidup dan cara bergaul generasi saat ini, generasi yang banyak orang menyebutnya sebagai generasi milenial. Peran orang tua dalam generasi ini cukup penting mengingat mudahnya seorang anak dalam mengases informasi.

Nurrachmawati (2014) menambahkan bahwa PC tablet atau smartphone tidak hanya berisi aplikasi tentang pembelajaran mengenal huruf atau gambar, tetapi terdapat aplikasi hiburan, seperti sosial media, video, gambar bahkan video game. Pada kenyataannya, seseorang akan lebih sering menggunakan gawai untuk bermain game daripada untuk belajar ataupun bemain di luar rumah dengan teman-teman seusianya. Intensitas penggunaan gawai dapat dilihat dari seberapa seringnya seseorang menggunakan gawai dalam satu hari atau jika dilihat dari setiap minggunya berdasarkan dari berapa hari dalam seminggu seorang mahasiswa menggunakan gawai. Intensitas penggunaan gawai yang terlalu sering dalam sehari maupun seminggu pasti akan mengarah pada kehidupan seseorang yang cenderung hanya mempedulikan gawainya saja ketimbang dengan bermain di luar rumah. Ketika seseorang kompeten secara emosional, seseorang juga siap kompeten secara sosial. seseorang mampu berbagi pada orang lain, bisa mengikuti aturan main. seseorang yang cerdas secara emosional mampu mengendalikan emosi negatif.

Ada dua macam faktor yang berperan dalam mempengaruhi prestasi belajar mahasiswa dalam proses perkuliahan: 1) Faktor Eksternal adalah faktor yang berasal dari luar diri mahasiswa, seperti lingkungan keluarga, lingkungan sekolah dan lingkungan sosial; 2) Faktor Internal adalah faktor yang berasal dari dalam diri mahasiswa, seperti motivasi, kreativitas sikap, Intelegent Question (IQ), Emotional Question (EQ), Social Question, dan Adversity Question $(A Q)$. Banyak orang beranggapan bahwa yang lebih berperan dalam mempengaruhi prestasi belajar yaitu faktor IQ, mahasiswa yang memiliki IQ tinggi akan memiliki prestasi belajar yang tinggi sementara mahasiswa yang memiliki IQ rendah akan memiliki prestasi belajar yang rendah, ternyata anggapan ini tidak selamanya benar ada beberapa kasus pembelajaran justru sebaliknya. Hal ini banyak didukung oleh pernyataan dari para ahli bahwa faktor internal yang 
mempengaruhi keberhasilan mahasiswa secara individu dalam belajar bukan hanya dipengaruhi oleh IQ akan tetapi juga dipengaruhi oleh kecerdasan emosional (Emotional Intelligence).

Banyak penelitian-penelitian yang mengungkap tentang pengaruh gawai terhadap prestasi belajar, yang menarik dalam penelitian ini adalah penggunaan gawai secara intensitasnya terhadap kecerdasan emosional mahasiswa. Penelitian ini bertujuan untuk mengungkap: "Intensitas Penggunaan Gawai Terhadap Kecerdasan Emosional Mahasiswa".

\section{METODE PELAKSANAAN}

Metode yang digunakan dalam penelitian ini menggunakan metode survey, dengan populasi seluruh mahasiswa semester VII reguler sore Program Studi Pendidikan Ekonomi, Fakultas Ilmu Pendidikan, Universitas Panca Sakti Bekasi berjumlah 46 mahasiswa. Jumlah sampel penelitian merujuk pada tabel Isaac \& Michael dengan signifikansi 5\% sebanyak 43 mahasiswa, Teknik sampel yang digunakan yaitu teknik random sampling. Pengumpulan data berupa skor diambil dengan menggunakan instrumen Intensitas penggunaan gawai mahasiswa selama satu minggu dan instrumen kecerdasan emosional dalam bentuk instrumen skala sikap. Instrumen Kecerdasan emosional valid dan memiliki reliabilitas Alpha dimensi I 0,832, dan dimensi II sebesar 0,762 ,

Hipotesa penelitian: Diduga terdapat pengaruh Intensitas penggunaan gawai terhadap kecerdasan emosional mahasiswa. Analisis data penelitian dilakukan dengan terlebih dahulu mendeskripsiikan, selanjutnya dilakukan uji prasyarat dengan menguji normalitas dan homogenitas data, setelah didapatkan data yang normal dan homogen dilanjutkan dengan uji hipotesis dengan analisis regresi sederhana.

\section{HASIL PENELITIAN DAN PEMBAHASAN}

\section{Hasil Penelitian}

Setelah di dapat data penelitian selanjutnya data dideskripsikan sebagai berikut: untuk variabel 1) Intensitas penggunaan gawai jumlah sampel atau responden sebanyak 43 mahasiswa dengan skor terendah 5 dan skor tertinggi 68, dengan rata-rata skor (mean) sebesar 26.28, rentang skor 63, simpangan baku atau standard deviasi 13.408, skor yang sering muncul (modus) 37, nilai tengah (median) 26.00; 2) Kecerdasan Emosional jumlah sampel atau responden sebanyak 43 
mahasiswa dengan skor terendah 45 dan skor tertinggi 118, dengan rata-rata skor (mean) sebesar 76.28 , rentang skor 73 , simpangan baku atau standard deviasi 13.400 , skor yang sering muncul (modus) 87, nilai tengah (median) 76.00 .

Data penelitian yang telah dideskripsikan selanjutnya dilakukan uji prasyarat analisis data menggunakan program SPSS versi.20 yaitu dengan menguji normalitas dan homogenitas data. Uji normalitas data dengan meggunakan uji Kolmogorov-SmimovZ untuk 1) Variabel intensitas penggunaan gawai didapat nilai probabilitas ( $\mathrm{p}$-value) $=0,059>0,050$ atau Ho diterima. Dengan demikian, data Intensitas penggunaan gawai berdistribusi Normal; 2) Variabel kecerdasan emosional diperoleh nilai probabilitas ( $\mathrm{p}$-value) $=0,058>0,050$ atau Ho diterima. Dengan demkian, data kecerdasan emosional berdistribusi Normal.

Untuk mengetahui apakah sebaran data dari setiap variable tidak menyimpang dari ciri-ciri data yang homogen pengujian homogenitas dilakukan terhadap varian regresi dependen atau variable-variabel independen dengan menggunakan statistic maka dilakukan uji homogenitas yaitu uji levene. Dari hasil analisis pada tabel Test of Homogeneity of Variances, diperoleh Levene Statistic $=0,028 ;$ df $1=1 ;$ df2 = 85, dan p-value = 0,867 $>0,05$ atau Ho diterima. Dengan demikian, kedua kelompok data berasal dari kelompok yang homogen.

Hasil uji hipotesis dengan menggunakan SPSS 20 sebagai berikut: 1) Persamaan Regresi Linear. Diperoleh persamaan regresi: $\mathrm{Y}=32,341+0,652 \mathrm{X}$. Dari hasil analisis diperoleh $\mathrm{t}_{\text {hit }}=210,238$ dan $\mathrm{p}$-value $=0,000 / 2=0<0,05$ atau Ho ditolak. Dengan demikian."Intensitas Pengunaan Gawai berpengaruh positif terhadap Kecerdasan emosional". 2) Uji Linearitas dan Signifikansi Persamaan Regresi. Pengujian linearitas dan signifikansi persamaan regresi ditentukan berdasarkan ANOVA table dan ANOVAa, sebagai berikut. Hipotesis statistik: $\mathrm{Ho}: \mathrm{Y}=\mathrm{a}+\mathrm{Bx}$ (regresi linear); Ho $: \mathrm{Y}=\mathrm{a}+\mathrm{Bx}$ (regresi tak linear) Uji linearitas persamaan garis regresi diperoleh $\mathrm{F}_{\text {hit }}(\mathrm{TC})=32,341$, dengan $\mathrm{p}$-value $=0<0,05$. Hal ini berarti Ho diterima atau persamaan regresi $\mathrm{Y}$ atas $\mathrm{X}$ adalah linear atau berupa garis linear. Hipotesis statistik: Ho $: \mathrm{b}=0$ (regresi tak berarti); Hi : $b=0$ (regresi bearti) Uji signifikansi persamaan garis regresi diperoleh $F_{\text {hit }}(\mathrm{b} / \mathrm{a})=32,341$, dan $\mathrm{p}$-value $=0,000<0,05$ atau Ho ditolak. Dengan demikian, regresi $\mathrm{Y}$ atau $\mathrm{X}$ adalah signifikan atau Intensitas Penggunaan Gawai berpengaruh terhadap Kecerdasaan Emosional mahasiswa, ini berarti hipotesis penelitian didukung oleh data empiris. 3) Uji 
Signifikansi Koefisien Korelasi X dan Y. Hipotesis statistik: H0 : $\rho=0$; H1 $: \rho \neq 0$, Uji signifikansi koefisien korelasi koefisien korelasi $(\mathrm{rxy})=0,652$ dan $\mathrm{F}$ hit (Fchange) $=32,341$, dengan $p$-value $=0,000<0,05$. Hal ini berarti Ho ditolak. Dengan demikian, koefisien korelasi $\mathrm{X}$ dan $\mathrm{Y}$ adalah berarti atau signifikan. Sedangkan koefisien determinasi $\mathrm{R}$ Square $=0,652$, yang mengandung makna bahwa 65,2 \% variasi variabel Kecerdasan Emosional dapat dipengaruhi oleh variabel intensitas penggunaan gawai.

Untuk dapat memahami makna hasil penelitian secara menyeluruh, maka hasil analisis data penelitian di atas dapat diinterpretasikan sebagai berikut : 1) Persamaan Regresi Linear Regresi. Diperoleh persamaan linear $\mathrm{Y}=32,341+0,652 \mathrm{X}$ artinya skor $\mathrm{Y}$ dapat diprediksi melalui persamaan linear tersebut diatas; 2) Dari hasil analisis didapat Intensitas Penggunaan Gawai mahasiswa berpengaruh terhadap kecerdasan emosional, hal ini dapat dilihat p-value lebih kecil dari 0,05 . Oleh sebab itu dapat diinterpresentasikan bahwa Intensitas Penggunaan Gawai mahasiswa berpengaruh positif terhadap kecerdasan emosional mahasiswa. 3) Uji signifikansi persamaan persamaan garis regresi diperoleh $F_{\text {hit }}$ dan p-value lebih kecil dari 0,05 atau Ho ditolak. Dengan demikian, regresi $\mathrm{Y}$ atau $\mathrm{X}$ adalah signifikan atau Intensitas Penggunaan Gawai mahasiswa berpengaruh positif terhadap kecerdasan emosional mahasiswa; 4) Uji signifikansi koefisien korelasi diperoleh koefisien korelasi $(\mathrm{rxy})=0,652$ dan Fhit $($ Fchange $)=32,341$, dengan p-value lebih kecil dari 0,05. Hal ini berarti Ho ditolak. Dengan demikian, koefisien korelasi X dan Y adalah bearti atau signifikan. Sedangkan koefisien determinasi dari tabel di atas terlihat pada baris ke-2, yaitu $\mathrm{R}$ Square $=0,652$, yang mengandung makna bahwa 65,2 \% variasi variabel Kecerdasan emosional dapat dipengaruhi oleh variabel intensitas penggunaan gawai.

\section{Pembahasan}

Intensitas penggunaan gawai berpengaruh positif terhadap Kecerdasan emosional mahasiswa. Dengan demikian hipotesis kerja dalam penelitian ini didukung oleh data empiris.

Hasil penelitian ini mendukung pendapat Hadiwidjodjo, Psi (2014) yaitu: "Mempermudah Komunikasi. Gawai merupakan salah satu alat yang memiliki teknologi yang canggih. Jadi semua orang dapat dengan mudah berkomunikasi. Membangun kreatifitas anak (Gawai memberikan beragam informasi yang juga bisa mendorong anak menjadi lebih kreatif). Anak 
akan lebih mudah dalam mencari segala informasi dan berita yang dibutuhkan olehnya, terutama dalam hal belajar sambil bermain ataupun bermain sambil belajar. Dalam usia ini, anak memang masih berada di dalam masa yang mengasyikan untuk bermain. Namun tak melepaskan diri dari sebuah proses pembelajaran yang juga harus dilakukan".

Hal ini mendukung penelitian yang dilakukan oleh Ferliana (2016), hasil penelitian Ferliana merekomendasikan orang tua untuk dapat mengontrol dan mengawasi berapa lama seorang anak untuk dapat bermain dengan gawainya, hal lain yang harus dilakukan oleh orang tua mengawasi permainan atau tampilan yang ada dilayar kaca gawai yang di pegang oleh seorang anak. Permainan yang dibumbui dengan kekerasan saat ini cukup marak mewarnai layar gawai selain itu permainan yang berbau pornografi juga wajib untuk diawasi dan di kontrol oleh para orang tua saat ini. Kecerdasan emosional memiliki dua sisi yaitu memerlukan kepandaian mahasiswa untuk memahami emosi, dan memerlukan perasaan (emosi pikiran) mahasiswa untuk dapat mengembangkan kreativitas dan intuisi pada pikiran logis mahasiswa. Pentingnya kecerdasan emosional sebagaimana yang dikemukakan diatas menuntut orang tua bijak dalam memberikan gawai bagi putra putrinya yang berusia dini, mengingat pengaruh gawai sangatlah besar dalam membentuk tumbuh kembang karakter anak khusunya kecerdasan emosional dimana menurut Goleman merupakan salah satu yang menetukan keberasilan seorang dalam kehidupan dimasa yang akan datang dimana masa tersebut merupkan suatu masa dimana peran teknologi sangat dominan, banyak orang menyebut masa itu sebagai revolusi industri 4.0. Lebih jauh lagi negara lain sudah mempersiapkan pada era revolusi society 5.0 dimana kecerdasan emosional sangat berperan di era itu, adanya revolusi 4.0 yang berusa untuk menyingkirkan peran manusia melalui artivisal intelegence atau lebih di kenal dengan kecerdasan buatan, sehingga legara negara maju seperti jepang mulai mengembangkan robot robot yang humanis yaitu robot robot yang ramah pada bentuk interaksi antar sesama manusia. Dengan demikian kecerdasan emosional dimana didalamnya meliputi pemahaman diri serta kepekaan sosial atau empati.

\section{SIMPULAN}

Dari hasil penelitian dan pembahasan dapat disimpulkan: 1) Intensitas penggunaan gawai berpengaruh terhadap kecerdasan emosional mahasiswa; 2) Regresi $\mathrm{Y}$ atau $\mathrm{X}$ adalah signifikan atau intensitas penggunaan gawai berpengaruh terhadap kecerdasan emosional mahasiswa; 3) 
Koefisien korelasi X dan Y adalah berarti atau signifikan. Sedangkan koefisien determinasi dari tabel di atas terlihat pada baris ke-2, yaitu R Square $=0,652$, yang mengandung makna bahwa $65,2 \%$ variasi variabel prestasi tugas akhir

\section{REFERENSI}

Akhir, Y. A. 1988. Menuju Keberhasilan Pribadi dengan IQ, Keterampilan Sosial, dan Kematangan Emosi. Makalah Seminar Sehari. Jakarta: UI.

Alder, H. 2001. Boost Your Intelligence, terjemahan Kristina Prianingsih. Jakarta: Erlangga,.

Anwar, S. 2010. Penyusunan Skala Psikologi. Yogyakarta: Pustaka Pelajar.

Arikunto, S. 2009. Manajemen Penelitian. Jakarta: PT Rieka Cipta.

Bloom, B.S. 1981. Taxonomy of Educational Objective. Handbook I. New York: Xongman Inc.

Kerlinger, F. N. 2006. Asas-Asas Penelitian Behavioral. Yogyakarta: Gadjah Mada University Press.

Supriyadi. 2018. Pengaruh Pendekatan Pembelajaran, Kecerdasan Emosional dan Kecerdasan Adversitas terhadap Hasil Belajar Videografi, Disertasi. Jakarta: Universitas Negeri Jakarta

Prawitasari, J. E. 1995. Mengenal Emosi Melalui Komunikasi Nonverbal. Yogyakarta: Fakultas Psikologi UGM,

Seniati, L. 2006. Psikologi Eksperimen. Jakarta: PT Intan Sejati Klaten.

Surapranata, S. 2003. Analisis, Penskoran, dan Interpretasi Hasil Tes, Modul. Aksara.

Slameto. 1987. Belajar dan Faktor-faktor yang Mempengaruhinya. Jakarta: PT. Bina

Syah, M. 1995. Psikologi Pendidikan Suatu Pendekatan Baru. Bandung: PT. Remaja Rosdakarya.

Wagner. 1993. Perkembangan Psikologi Anak, terjemahan Rudi handoko. Jakarta: PT Gramedia.

Winkel W.S. 1987. Psikologi Pendidikan dan Evaluasi Belajar. Jakarta: Gramedia. 